\title{
Building bridges, fording streams, reaching agreement in the Lake Champlain basin: Alternatives to legislation and regulation rooted in citizen and science-based approaches to inspire watershed protection"
}

\author{
Michaela Stickney* \\ Lake Champlain Basin Program, Lake Champlain Basin Program and Vermont Agency of Natural Resources, \\ 103 South Main Street, Center Building, Waterbury, Vermont, 05671-0309 USA
}

\begin{abstract}
Challenges and opportunities arise when jointly managing international waters shared by two countries and two states with different political and governmental systems. Lake Champlain's vast watershed is shared by the states of Vermont and New York in the United States of America and the Province of Québec in Canada. Transboundary relations are characterised by consensus reached through a continuous sequence of non-binding, non-regulatory environmental agreements. Since the historic 1988 Memorandum of Understanding on Environmental Cooperation on the Management of Lake Champlain, 16 additional agreements have been signed - averaging nearly one per year. They range from joint declarations and watershed plans to phosphorus standards and toxic spill responses. They are renewable agreements bearing the support and participation of state, provincial and federal agencies; local government; and businesses with a very strong citizen component. This progression of cooperative agreements falls under the auspices of the Lake Champlain Basin Program, a quasi-governmental partnership among Vermont, New York and Québec that coordinates Lake Champlain's long-term management plan, Opportunities for Action: An Evolving Plan for the Future of the Lake Champlain Basin. The Lake Champlain Basin Program achieves significant watershed improvements through its consensus-based, decision-making policies bolstered by state-to-state, state-to-province agreements. This incremental approach, steeped in multi-level partnerships and institutions, epitomises the theory of natural resource regimes which emphasise roles of intermediate institutions in environmental management. Use of non-binding, renewable agreements more easily bridges differences among jurisdictions, whether interstate, intrastate or international. Additionally, such agreements can be updated more immediately as new information and technologies emerge. Voluntary, renewable agreements can be assembled more quickly than pursuing a traditional regulatory or legislative response. It is precisely the voluntary nature of these agreements and their successes that has captured the attention of other basins worldwide as a model for replication and reaching agreement on difficult issues.
\end{abstract}

Keywords: transboundary, decision-making, watershed planning, integrated water resources management (IWRM), Lake Champlain, consensus, collaboration, stakeholder participation, stakeholder involvement, lake management

\section{Lake Champlain background}

\section{Introduction}

The Lake Champlain Basin Program is a model of participatory, watershed-based natural resource protection that involves citizens, businesses, local and regional government, educational institutions, and nongovernmental organisations in decisionmaking and planning. The Basin Program's success is rooted in consistent adherence to: partnership and collaboration; a multiple stakeholder approach that relies on citizen participation; dissemination of information to the public; and basing management decisions on reliable, proven science. It is not a regulatory program, has no statutory authority, and does not engage as a

Revised paper. Originally presented at the symposium 'HELP in Action: Local Solutions to Global Water Problems - Lessons from the South' which was held at the Emperor's Palace, Johannesburg, South Africa from 4 to 9 November 2007.

* To whom all correspondence should be addressed.

+1 (802) 241-3619; fax: +1 (802) 241-3796;

e-mail: michaela.stickney@state.vt.us party to regulatory processes (Stickney et al., 2001).

A succession of recurrent, incremental, voluntary bilateral and trilateral agreements in the Lake Champlain Basin have: strengthened transboundary cooperation; advanced watershed protection achievements beyond regulatory and legislative requirements; and bridged the gap between science and public policy by basing decision-making on sound science and making science understandable to the general public. Use of nonbinding, renewable agreements more easily bridges differences among jurisdictions, whether interstate, intrastate or international. They can be timelier than pursuing a traditional regulatory or legislative response. Additionally, such agreements are more responsive as they can be updated more immediately as new scientific information, technologies and solutions emerge.

\section{Lake Champlain description}

Lake Champlain's vast watershed is shared by Vermont, New York and Québec. The basin extends from peaks of the Adirondack Mountains in New York east towards the Green Mountains in Vermont and north into Québec. Through the Richelieu River, Lake Champlain shares the St. Lawrence River drainage north 


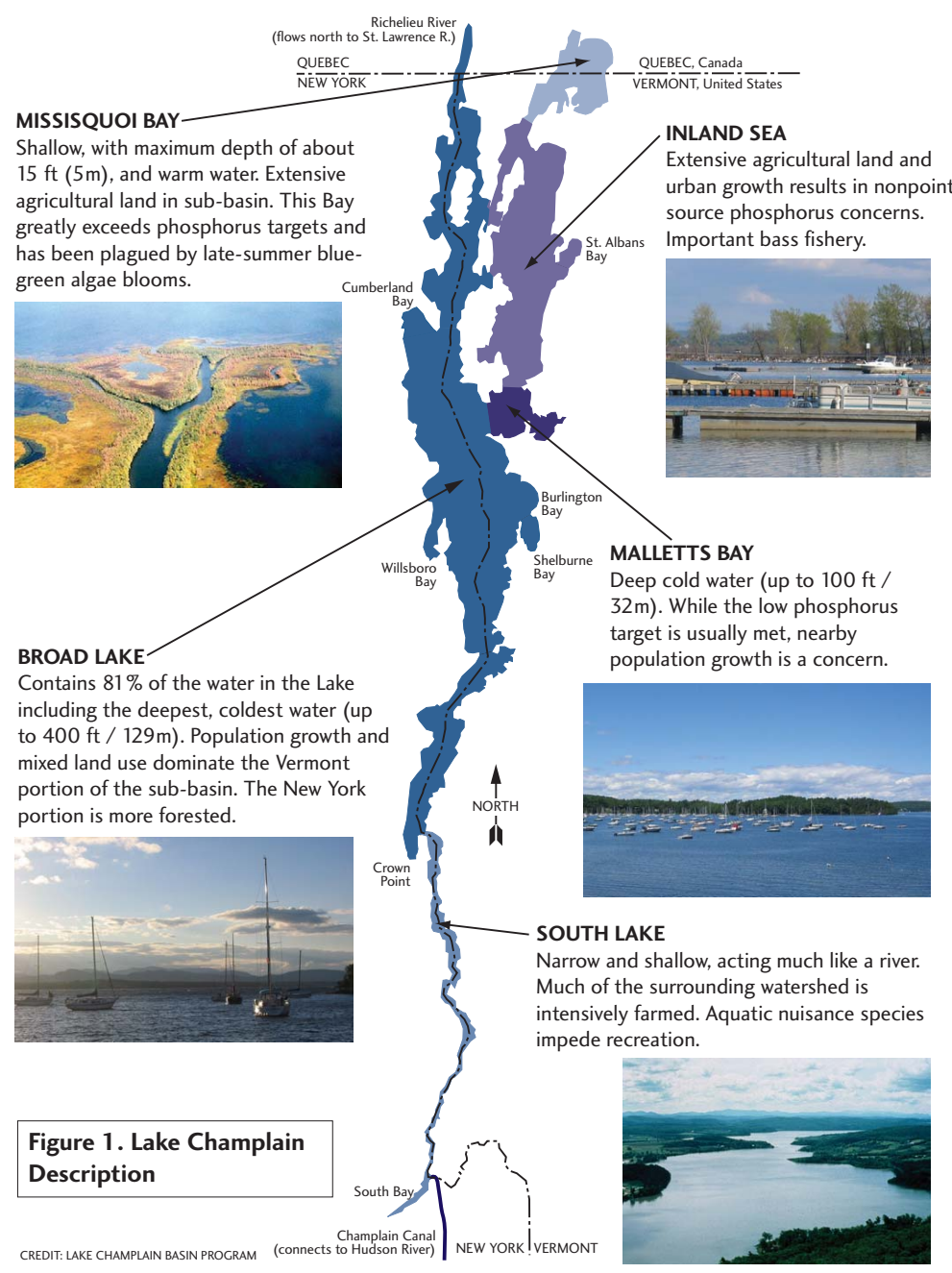

among the various sub-watersheds. Agricultural land use was still the greatest contributor of phosphorus (about 70\%) in the Missisquoi Bay subwatershed (Troy et al., 2007). While only $7 \%$ of the watershed lies in Québec, Vermont and Québec share Missisquoi Bay, the single most impaired region of Lake Champlain. Therefore, Québec's participation is crucial to the health of the rest of the lake.

To better understand how Vermont, New York and Québec have overcome historical differences, it is helpful to illustrate how their political boundaries, geographic identities and population characteristics are manifested. In Vermont, citizens have significantly stronger political identities at the town level than at the larger county or state levels. Therefore, there are high levels of participation and action at the local level regarding Lake Champlain clean-up activities. There are 136 Vermont towns in the Lake Champlain Basin and $47 \%$ of the state is physically located within the Basin. Most of these towns have populations ranging from $1000-4000$ people. In New York, citizens tend to have stronger political identities at the county level. There are four major counties in the New York part of the Basin. Québec citizens often identify themselves by federally designated regions called Regional County Municipalities (MRC). The Montérégie MRC includes the small portion of Québec in the Basin (Lake Champlain Basin Program, 2004). These radically different geographic identities can challenge the cohesiveness of watershed protection and restoration efforts. However, the structure of the Lake Champlain Basin Program allows various political interests to be thoroughly and openly discussed, and as a result political will supporting watershed protection and restoration is threaded throughout these various local, regional,

to the Atlantic Ocean with the Great Lakes in the Midwestern United States. From north to south, the lake spans $193 \mathrm{~km}$, yet it is surprisingly narrow - only $19 \mathrm{~km}$ at its widest point. Its greatest depth is $122 \mathrm{~m}$ and the watershed is $21326 \mathrm{~km}^{2}$ (Lake Champlain Basin Program, 2003).

Lake Champlain's long length and narrow width, in addition to many bays and 70 islands, contribute to the lake being divided into five major segments and many smaller bays. Each segment has unique physical characteristics and different land uses in its surrounding subbasin which influence the water quality of that segment (Fig. 1). Consequently, many concerns for Lake Champlain are location-specific. While extensive blue-green algae blooms are a serious problem in Missisquoi Bay, they have not proved problematic in the South Lake (Lake Champlain Basin Program, 2005). For phosphorus targeting purposes, the lake basin is further subdivided into 13 lake segments and 19 subwatersheds.

According to 2000 United States and Canadian census data, the Lake Champlain Basin population is 571000 people, and as it rises, evolving impacts on the lake continue to cause concern. The overall watershed land cover is about $66 \%$ forested, $14 \%$ agricultural, $5 \%$ urban and suburban, and $15 \%$ water and wetlands as shown in Fig. 2. A new (2007) land use and land cover study of the basin indicated that urban and suburban land (only $5 \%$ of land cover) contributed about $46 \%$ of phosphorus runoff to Lake Champlain overall and agricultural lands contributed about $38 \%$. However, these proportions varied significantly and federal levels.

Population and urban centre locations also affect differences among the three jurisdictions. Vermont is one of the smallest states in the United States. Of the 609000 Vermont residents, $64 \%$ or 390000 live within the Lake Champlain Basin and there are three major cities with populations ranging between 15000 to 39000 people. Conversely, New York is one of the larger states in the United States with a population of 19 million people, yet the New York portion of the Lake Champlain Basin has only 151000 people (Lake Champlain Basin Program, 2004). It is common in Vermont to see elected federal and state officials walking down the street, and Vermont's capital city is located within the Basin, while New York's capital Albany and economic centre of New York City are well outside the Basin. Since most of the Vermont population lives within the Basin, it is easier to engage citizens in Lake Champlain issues, unlike New York, which also contains other internationally recognised water bodies such as Lake Ontario of the Great Lakes system and the Finger Lakes. While the Montérégie MRC has 1.4 million residents and includes the city of Montreal, only 30000 people live in the portion of Québec that lies within the Lake Champlain Basin. Québec residents use two languages - French and English - with French as the dominant language which requires language interpretation and document translation. With help from our Québecois partners, the LCBP offers major documents in French to help bridge differences and promote mutual understanding. 


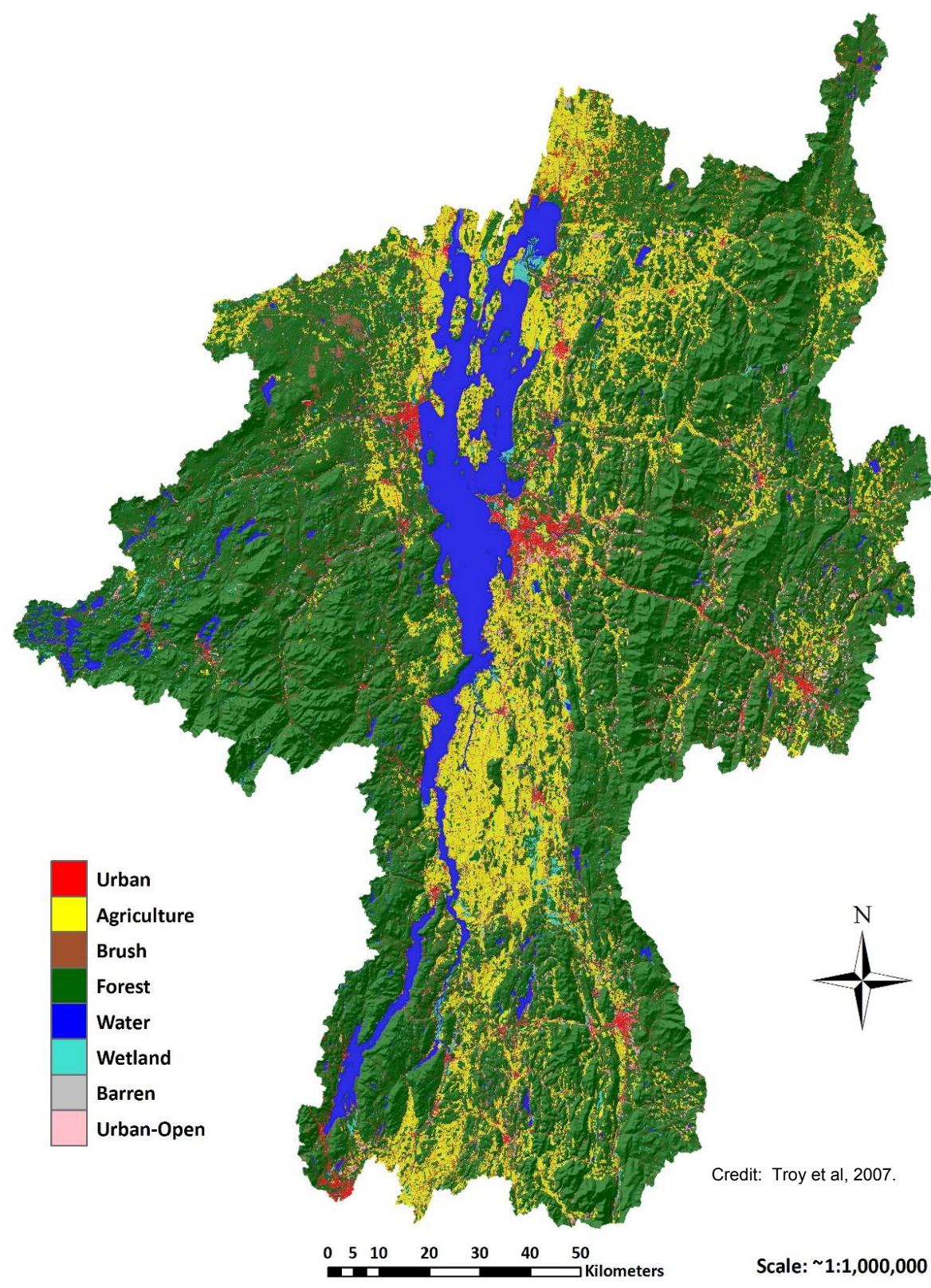

Figure 2. Lake Champlain Basin land use and land cover.

\section{Inclusive committee structure}

The Lake Champlain Basin Program committee structure offers many opportunities and varying roles for stakeholder participation. Multiple stakeholders from the three jurisdictions of Vermont, New York and Québec represent local, state, provincial, and federal partners (Fig. 3, next page). There is a high level of citizen involvement. The Citizens Advisory Committees of Vermont, New York and Québec are independent committees representing recreation, tourism, agriculture, business, and cultural heritage interests, environmental advocacy groups, and legislative leaders. They advise the public about lake issues and listen to citizen concerns. The Basin Program also has a Technical Advisory Committee, Education and Outreach Committee and a Cultural Heritage and Recreation Advisory Committee. All six advisory committee chairs have a seat on the Lake Champlain Steering Committee, the governing body for the Lake Champlain Basin Program (Lake Champlain Basin Program, 2003; Howland et al., 2003).

\section{Partnerships}

Successful implementation of Opportunities for Action is achieved by developing many partnerships. As a neutral party with the participation and support of scientists, policymakers, citizens, and resource managers, the Basin Program transcends litigation, political elections, and regulation to offer a truly integrated partnershipbased dialogue for solving difficult problems. To implement the plan, the Lake Champlain Basin Program

\section{Lake Champlain Basin Program - a model for originality and innovation in stakeholder involvement}

The Lake Champlain Basin Program is a quasi-governmental, public-private partnership among Vermont, New York and Québec with federal funding that coordinates Lake Champlain's long-term management plan Opportunities for Action: An Evolving Plan for the Future of the Lake Champlain Basin. The Lake Champlain Basin Program achieves significant watershed improvements through its consensusbased, decision-making policies supported by state-to-state, state-to-province agreements. This incremental approach emphasises partnerships, local actions and involvement of citizens. The Lake Champlain Basin Program offers a proven, original process that can be transferred to other basins. makes grant awards to citizen, watershed, municipal, government, and business groups. Since 1992, more than US\$3 million have been spent on over 600 projects to reduce phosphorus, prevent the spread of invasive aquatic species, improve watershed education, and attain lake improvement goals (Lake Champlain Basin Program, 2006).

\section{Consensus}

Consensus and trust-building have helped Vermont, New York and Québec leaders overcome policy conflicts. A consensus approach to decision-making creates a win-win atmosphere where minority opinions are usually incorporated into decisions that pass by majority vote. This process encourages open and public discussion, so that committee members can freely explore decisions before making commitments. While the consensus process minimises conflict, it does require that they share common goals. The consensus approach gives participants a 


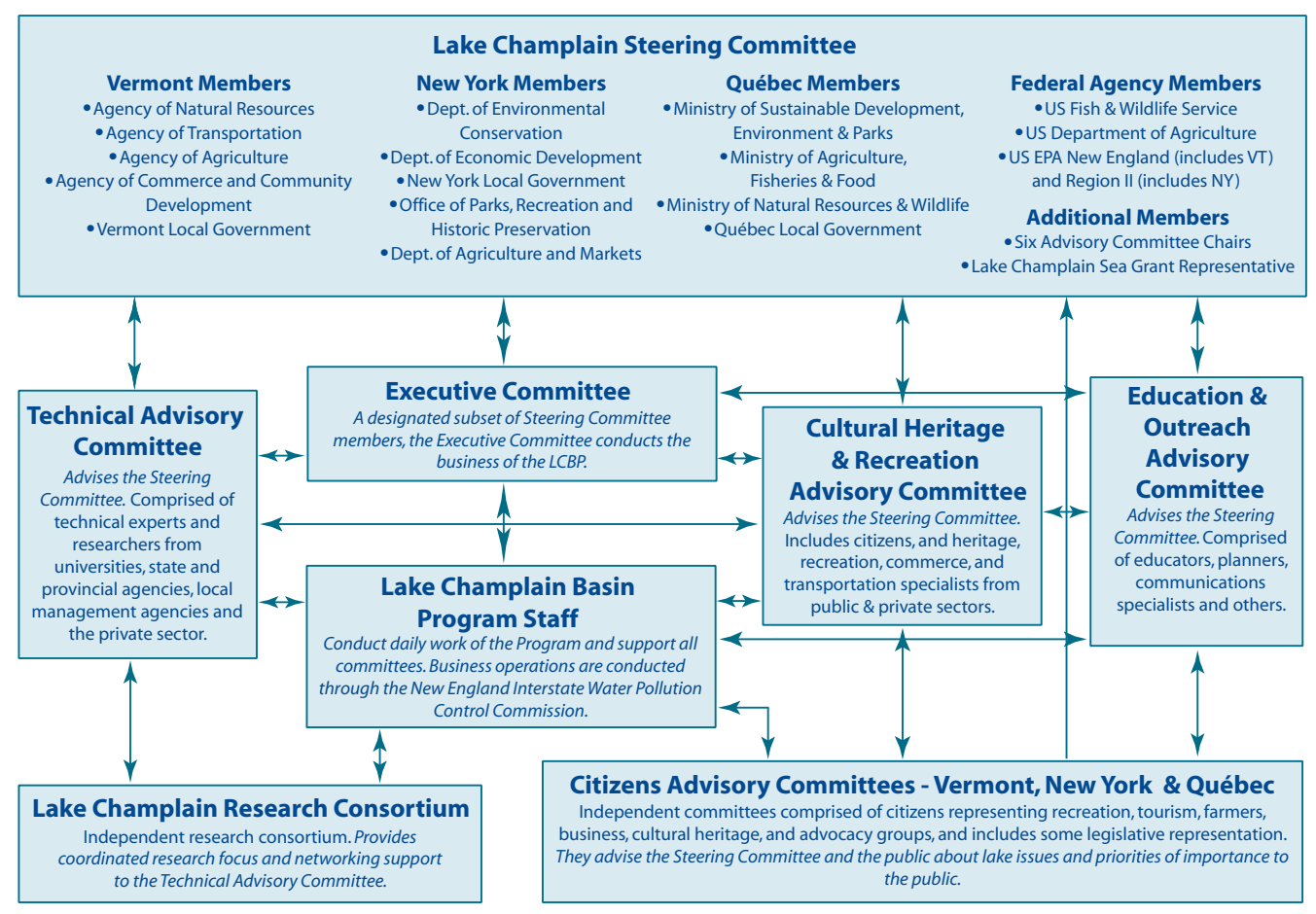

Figure 3

Lake Champlain

Basin Program

inclusive committee structure meaningful role in developing viable solutions and results in group ownership of decisions unattainable through other means (Howland et al., 2003).

\section{Effective framework}

The Lake Champlain Basin Program forms an effective framework for water policy leaders, water resource managers, and scientists to work collaboratively. This proven framework defines watershed management issues according to the needs of the watershed residents or "users." A user-driven approach requires active involvement of policy and citizen groups to ensure scientific investigations will benefit community needs. Because policy leaders and resource managers contend with legal, institutional, regulatory, and economic interests, they need to understand which scientific information is most needed and communicate these needs to scientists. The Lake Champlain Basin Program annually funds more than US\$500 000 (US Dollars) for research and education in the basin. Trend analysis of long-term lake monitoring data allows scientists, resource managers and policy leaders to determine whether management goals and targets are on track and being met.

\section{Sequence of incremental, bilateral or trilateral agreements}

Since the historic 1988 Memorandum of Understanding on Environmental Cooperation on the Management of Lake Champlain, 16 additional agreements have been signed - averaging nearly one per year. They range from joint declarations and watershed plans to phosphorus standards and toxic spill responses. They are renewable agreements bearing the support and participation of state, provincial and federal agencies; local government; and businesses with a strong citizen component (Stickney, 2003). They have been signed by governors and premiers, state and federal natural resource policy leaders, senators and mayors, and non-governmental organisations (Fig. 4).

\section{Memorandum of Understanding - Vermont, New York and Québec - 1988, 1992, 1996, 2000, 2003 and 2009 (expected)}

The Governors of Vermont and New York and the Premier of Québec opened a new era of cooperation on lake management in 1988 by signing the Memorandum of Understanding on Environmental Cooperation on the Management of Lake Champlain. This agreement:

- Created a mechanism for the exchange of scientific information

- Encouraged cooperative planning for environmental protection

- Addressed the lake and its watershed

- Established the Lake Champlain Steering Committee with diverse representation among Vermont, New York and Québec

- Established Citizens Advisory Committees in the three jurisdictions

- Designated a timeline for the memorandum to be renewed every four years.

Each renewal has reconfirmed the commitment of Vermont, New York and Québec to continue multi-level, multi-sector partnerships for managing, protecting and improving the Lake Champlain Basin. In 2003, the renewal schedule was changed to five years to coincide with the renewal schedule for Opportunities for Action (Vermont State, New York State, and Québec Province, 2003).

Most importantly, the memorandum charged the signatories with a three-step phosphorus management strategy to establish numeric in-lake phosphorus concentration criteria for each lake segment; develop a lake model predicting the response to changing phosphorus loads; and use the lake model to conduct a phosphorus load allocation at tributary mouths and set phosphorus targets.

\section{Special Designation Act - Vermont and New York - 1990, 2002 and 2009 (expected)}

The Lake Champlain Special Designation Act (Public Law 101596) passed by Congress created the Lake Champlain Basin 

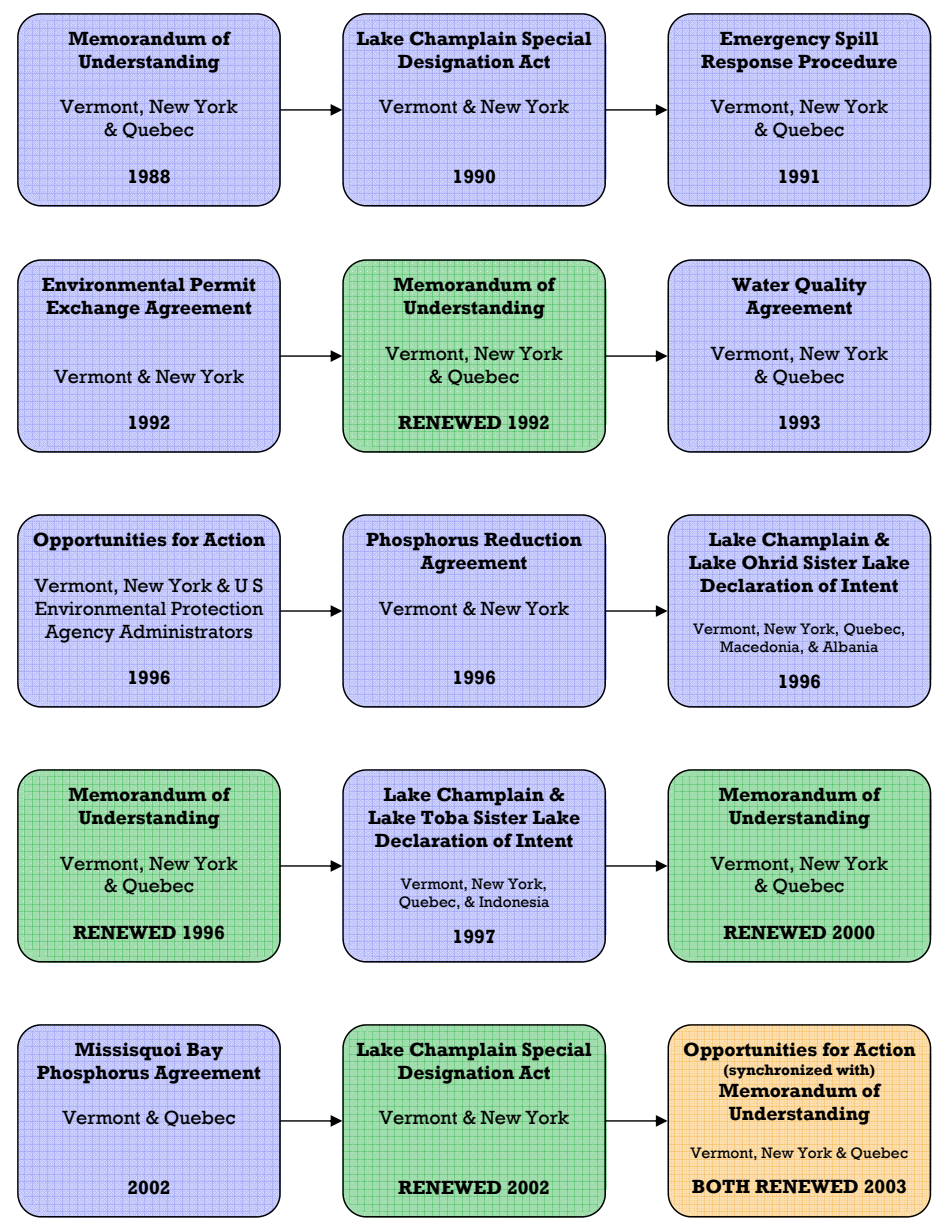

Figure 4

Chronology of incremental trilateral and bilateral agreements

Program. Specifically it:

- Charged the Lake Champlain Basin Program to develop a watershed management plan that became Opportunities for Action

- Established the technical and education and outreach advisory committees

- Clarified that the Basin Program would enhance activities of existing federal natural resource agencies in the United States, such as the Department of Agriculture, Fish and Wildlife Service, National Park Service, and Geological Survey, and not to replace their long-time efforts

- Authorised up to a maximum of US\$5 million annually from the United States Environmental Protection Agency for five years (Lake Champlain Basin Program, 2003).

In 2002, the act was reauthorised to provide up to a maximum of US $\$ 11$ million for 5 years. The Lake Champlain Basin Program has received roughly US $\$ 1.5$ million to $\$ 2$ million annually for its operations.

Emergency spill response joint procedure for incidents impacting Lake Champlain or its tributaries - Vermont, New York and Québec - 1991 and 2008 (expected)

This procedure was developed as a companion to the original memorandum. The Emergency Spill Response Joint Proce- dure was developed to provide rapid notification and a coordinated response to toxic spills. Each jurisdiction will notify the other of any release, spill or discharge of petroleum and/or hazardous material into Lake Champlain, its tributaries and near shore transportation corridors and facilities (Vermont Agency of Natural Resources, New York State Department of Environmental Conservation, and Québec Ministry of Environment, 1991). After a sewer line break that sent raw sewage directly into Lake Champlain was detected in Canada through monitoring, sewage spills have been added to a draft emergency spill response document expected to be renewed in 2008 .

\section{Permit Exchange Agreement - Vermont and New York - 1992 and 2008 (expected)}

This agreement is also a companion to the original memorandum. It facilitates a regulatory information exchange between the states and assures the public that each state can participate in appropriate permit proceedings of the other. The permit exchange covers specific regulated activities of wastewater treatment plants, construction or expansion of commercial marinas, wetland disturbance contiguous with the lake, solid or hazardous waste disposal, and air pollution sources within $80 \mathrm{~km}$ of the lake (Vermont Agency of Natural Resources and New York State Department of Environmental Conservation, 1992).

\section{Water Quality Agreement - Vermont, New York and Québec - 1993}

The governments of Vermont, New York and Québec committed to a consistent approach for phosphorus management of Lake Champlain. The Water Quality Agreement established in-lake phosphorus criteria that need to be met for 13 lake segments of Lake Champlain. Concurrently, Vermont and New York conducted the Lake Champlain Diagnostic Feasibility Study to generate baseline information as called for in the original memorandum. Then they developed an optimisation procedure to determine the cost-effectiveness of various strategies for attaining the in-lake phosphorus criteria. Designed for use with the Lake Champlain Diagnostic Feasibility Study, the optimisation procedure took into account the costs of phosphorus reduction strategies achievable from point and non-point sources, as well as how changes to phosphorus levels in one lake segment might affect levels in others (Vermont Agency of Natural Resources, New York State Department of Environmental Conservation, and Québec Ministry of Environment, 1993; Lake Champlain Basin Program, 2003).

\section{Opportunities for Action - Vermont, New York and United States Environmental Protection Agency - 1996, 2003 and 2009 (expected)}

In 1996, the Lake Champlain Basin Program released Opportunities for Action: An Evolving Plan for the Future of the Lake Champlain Basin. The guiding themes of this restoration plan included the:

- establishment of partnerships among diverse stakeholders;

- a watershed-based planning and management approach;

- integration of environmental and economic goals; and

- an emphasis on flexible pollution reduction options. 
As its title indicated, the plan has and is evolving and has been responsive to emerging research needs and discoveries, changes in public policy and evolving needs of the basin's citizens. The Governors of Vermont and New York, Premier of Québec and Regional Administrators of the United States Environmental Protection Agency signed the plan.

The plan's four highest priorities are to:

- reduce phosphorus inputs to Lake Champlain and provide for sustainable human use and enjoyment of the lake;

- reduce toxic contamination to protect public health and the Lake Champlain ecosystem;

- minimise the risks to humans from water-related health hazards, especially from toxic blue-green algae blooms and other water-borne pathogens; and

- control the introduction, spread and impact of non-native aquatic nuisance species in order to preserve the integrity of the Lake Champlain ecosystem.

There are also chapters addressing fish and wildlife protection, wetlands, cultural heritage resources, recreation opportunities, and economics with over 100 actions overall ranked by priorities established through public meetings. The most current revision of Opportunities for Action called for more aggressive phosphorus reduction, particularly from urban, suburban and rural non-point sources (Howland et al., 2003; Lake Champlain Basin Program, 2003).

\section{Phosphorus reduction agreement - Vermont and New York - 1996}

The state governments of Vermont and New York divided responsibilities for reducing phosphorus loading; established phosphorus load reduction targets for 19 sub-watersheds within the Lake Champlain Basin; and selected a 20-year timeline to achieve phosphorus reduction targets called for in Opportunities for Action (Vermont Department of Environmental Conservation and New York State Department of Environmental Conservation, 1997). This agreement created a basis for the Lake Champlain Phosphorus Total Maximum Daily Load (TMDL), a federally required phosphorus allocation and reduction program. Strong public interest in shortening the 20-year timeline inspired Vermont's Clean and Clear Action Plan which has accelerated funding for the TMDL, estimated to cost more than US\$140 million(Vermont Agency of Natural Resources and New York State Department of Environmental Conservation, 2002; Vermont State, 2003).

\section{Lake Champlain and Lake Ohrid Sister-Lakes Decla- ration of Intent - Macedonia, Albania, Vermont, New York, and Québec - 1996}

The Lake Champlain Basin Program is recognised internationally, especially among former Soviet-block countries, as a successful model of integrated, participatory, watershed management. The Sister-Lake Declaration of Intent committed state and provincial agencies from Vermont, New York and Québec to disseminate information on successful lake management practices; conduct peer-to-peer exchanges among technical experts and community leaders; institute team-building for improved transboundary relations; and share institutional arrangements and flexible agreements. The Macedonians and Albanians selected the Lake Champlain Basin Program because of its participatory spirit and the integration of cultural heritage and recreational access opportunities as high priorities in
Opportunities for Action (Institute for Sustainable Communities, 1996; Stickney, 2001).

\section{Lake Champlain and Lake Toba Sister-Lakes Declara- tion of Intent - Indonesia, Vermont, New York, and Québec - 1997}

The following year a similar voluntary, multilateral agreement was signed with peers in Indonesia. As with Lake Ohrid, Indonesian partners approached the Lake Champlain Basin Program and proposed signing the agreement to formalise relations (Lake Toba Heritage Foundation, 1997).

\section{Missisquoi Bay Phosphorus Agreement - Vermont and Québec - 2002}

This agreement was the result of several years of work by the Missisquoi Bay Phosphorus Reduction Task Force. Convened by the Province of Québec and State of Vermont, this task force was facilitated largely by the Lake Champlain Basin Program (Missisquoi Bay Task Force, 2000). The resulting agreement determined a division of responsibility between Vermont and Québec for phosphorus load reduction in Missisquoi Bay. The resulting division was $60 \%$ Vermont and 40\% Québec, unlike the anticipated 50/50 division (Québec Ministry of Environment and Vermont Agency of Natural Resources, 2002).

\section{Lessons learned to be shared with other lakes and river basins}

- A consensual policy style vs. an adversarial policy style results in reliable and evolving commitments by Vermont, New York and Québec. Nearly one agreement has been signed each year on average among two or three of the jurisdictions which reaffirms their continuing commitment towards shared management of the Lake Champlain Basin. This approach encourages a higher level of participation in watershed cleanup activities than required by bureaucratic regulation.

- Less regulation and renewable, flexible agreements result in substantial financial commitments by Vermont, New York and Québec. In partnership with the Lake Champlain Basin Program, the three jurisdictions have invested millions of dollars annually, primarily to reduce point source phosphorus pollution and cleanup hazardous waste dumps, and also for aquatic nuisance species control and water quality research. Partnering with the basin program allows the three jurisdictions to plan lake and watershed improvements proactively for their respective geographic regions without being required to do so.

- Political will supports sustainability of the Lake Champlain Basin Program and observance of its operating principles. The signatures of the Governors of Vermont and New York, Premier of Québec and the Regional Administrators of the United States Environmental Protection Agency give the Opportunities for Action management plan significant credibility. The non-binding, voluntary and incremental aspects of signing agreements encourages their participation while still allowing for different implementation styles and creative thinking such as Vermont's Clean and Clear Action Plan, New York's Clean Air/Clean Water Bond Act (New York State, 1995), and Québec's new, model, extensive riparian buffer policies. 
- Leadership by key individuals serves an important role in solving transboundary challenges. The Lake Champlain Basin Program process involves multiple committees, task forces and public meetings. Participation by high-ranking individuals, such as city mayors, executive directors, legislators, and natural resource policy leaders garners support within larger audiences and attracts significant funding and far-reaching collaboration.

- A built-in renewal schedule for voluntary bilateral and trilateral agreements results in immediacy and accountability. Voluntary agreements evolve more rapidly than traditional regulation and legislation. Regularly revisiting agreements allows emerging scientific information and public needs to be incorporated quickly to improve accountability. Currently, the emergency spill response and permit exchange agreements, which lack built-in renewal schedules, need updated procedures. There have been a few incidents on Lake Champlain where either the wrong individuals were contacted regarding an emergency spill, or new staff did not follow the procedure because it was out of date (Stickney, 2003; 2006).

- "Leapfrogging" or developing agreements incrementally keeps them linked together and looking forward. The original 1988 Memorandum of Understanding called for a cooperative approach to lake management and for inlake phosphorus criteria to be developed in the future. The 1993 Water Quality Agreement established in-lake phosphorus criteria and called for phosphorus loading targets to be developed in the future. The 1996 Phosphorus Reduction Agreement established phosphorus loads and called for Vermont and Québec to divide responsibility for reducing phosphorus in Missisquoi Bay. The Missisquoi Bay Agreement established the division of responsibility between Vermont and Québec. Each agreement made progress and set a future target that was met within a few years (Stickney, 2003; 2006).

\section{Conclusion}

Natural resource regimes are intended to solve transboundary problems, and in the process, to institutionalise cooperation and well-defined issue areas. Natural resource regimes are characterised by inter-jurisdictional management of transboundary environmental problems; consensus-based decision-making; a watershed approach to planning; individual leaders playing key roles in facilitating the process; and favouring common interests over singular interests of one group. They emphasise roles of intermediate institutions in environmental management (Drost and Brooks, 1997; Young, 1997), such as through multi-level, multi-sector partnerships. Within this framework, the Lake Champlain Basin Program, through Lake Champlain's longterm management plan Opportunities for Action, has institutionalised a cooperative structure focused on phosphorus reduction, toxic substance control, human health protection, and aquatic nuisance species spread prevention. The federal governments of Canada and the United States have not entered into an intergovernmental agreement regarding management of Lake Champlain. Lack of bilateral arrangements at the intergovernmental (federal) level has stimulated efforts by Vermont, New York and Québec to develop transboundary arrangements among themselves to solve environmental problems and challenges. While some see this gap as evidence of the need to generate political will to create a federal level treaty, others look to the potential for transboundary arrangements initiated by Vermont, New
York and Québec and question the need for federal level agreements in solving the lake's problems.

A legacy of this approach to transboundary relations and watershed protection is that to date, none of these voluntary, incremental, collaborative agreements have been contested among the jurisdictions or in court. Success in continually securing funding commitments creates a win-win situation among the jurisdictions and leverages more funding and action. While it appears there are many agreements overall, the fact that the agreements are linked and have been used as the foundation for other legislation and regulation is enduring and important. More significant agreements are currently on the horizon. The year 2009 marks the $400^{\text {th }}$ Anniversary of Samuel de Champlain's arrival to the lake that bears his name. Then, the Lake Champlain Basin Program plans to have revised versions of Opportunities for Action, the Memorandum of Understanding, and the Special Designation Act adopted or reauthorised.

\section{References}

DROST A and BROOKS R (1998) Civil society regimes and ecosystem management: selected problems in Lake Champlain. Arizona J. Int. Comp. Law 15 289-317.

HOWLAND W, GRUESSNER B, LESCAZE $M$ and STICKNEY $M$ (2003) Lake Champlain: Experiences and lessons learned brief. In: Proc. for World Lake Basin Management Initiative, the Regional Workshop for Europe, Central Asia, and the Americas. June 18-21, 2003, St. Michael's College, Colchester, Vermont, USA.

INSTITUTE FOR SUSTAINABLE COMMUNITIES (1996) Lake Champlain and Lake Ohrid Sister Lakes Declaration of Intent. Institute for Sustainable Communities, Montpelier, Vermont, USA.

LAKE CHAMPLAIN BASIN PROGRAM (2003) Opportunities for Action: An Evolving Plan for the Future of the Lake Champlain Basin. Lake Champlain Basin Program, Grand Isle, Vermont, USA.

LAKE CHAMPLAIN BASIN PROGRAM (2004) Lake Champlain Basin Atlas Version 3.0. Lake Champlain Basin Program, Grand Isle, Vermont, USA.

LAKE CHAMPLAIN BASIN PROGRAM (2005) State of the Lake: Lake Champlain in 2005, a Snapshot for Citizens. Lake Champlain Basin Program, Grand Isle, Vermont, USA

LAKE CHAMPLAIN BASIN PROGRAM (2006) Progress 2006: A $15^{\text {th }}$ Anniversary Report about Lake Champlain's Restoration. Lake Champlain Basin Program, Grand Isle, Vermont, USA.

LAKE TOBA HERITAGE FOUNDATION (1997) Lake Champlain and Lake Toba Sister Lakes Declaration of Intent. Lake Toba Heritage Foundation, Jakarta, Indonesia.

MISSISQUOI BAY TASK FORCE (2000) A division of responsibility between Québec and Vermont for the Reduction of Phosphorus to Missisquoi Bay. Québec Ministry of Environment and Vermont Agency of Natural Resources, Montreal, Québec and Waterbury, Vermont, Canada and USA.

NEW YORK STATE (1995) Clean Air/Clean Water Bond Act. Governor's Office, Albany, New York, USA.

Québec MINISTRY OF ENVIRONMENT and VERMONT AGENCY OF NATURAL RESOURCES (2002) Agreement between the Government of Québec and the Government of Vermont Concerning Phosphorus Reduction to Missisquoi Bay. QMENV and VTANR, Montreal, Québec and Waterbury, Vermont, Canada and USA.

STICKNEY M, HICKEY C, and HOERR R (2001) Lake Champlain Basin Program: Working together today for tomorrow. Lakes and Reservoirs: Res. Manage. 6 217-223.

STICKNEY M (2001) Distant waters, sister lakes: Lake Champlain and Lake Ohrid's sister lakes partnership bridges transboundary relations. In: Proc. $9^{\text {th }}$ Int. Conf. Conserv. Manage. World Lakes. November 12-16, 2001, Shiga Prefectural Government. Shiga, Japan.

STICKNEY M (2003) Steps in rhythm: strengthening transboundary relations in the Lake Champlain Basin through voluntary incremental environmental agreements. In: Proc. 10 $0^{\text {th }}$ Int. Conf. Conserv. 
Manage. World Lakes. IAGLR/ILEC Global Threats to Large Lakes - Abstracts, DePaul University, Chicago, Illinois, USA. DATES: June 22-26, 2003

STICKNEY M (2006) Lake Champlain Local Action Summary. In: Proc. World Water Forum IV. March 16-22, 2006, Mexico City, Mexico.

TROY A, WANG D, CAPEN C, O'NEIL-DUNNE J and MACFADEN S (2007) Updating the Lake Champlain Basin Land Use Data to Improve Prediction of Phosphorus Loading. University of Vermont, Lake Champlain Basin Program Technical Report \#54, Grand Isle, Vermont, USA.

UNITED STATES OF AMERICA 107 ${ }^{\mathrm{TH}}$ CONGRESS (1990) Lake Champlain Special Designation Act and Statement of Legislative Intent. Public Law 101-596, November 16, 1990. Washington, DC, USA.

VERMONT AGENCY OF NATURAL RESOURCES, NEW YORK STATE DEPARTMENT OF ENVIRONMENTAL CONSERVATION, AND QUÉBEC MINISTRY OF ENVIRONMENT (1991) Emergency Spill Response Joint Procedure for Incidents Impacting Lake Champlain or its Tributaries. VTANR, NYSDEC, and QMENV, Waterbury, Vermont, Albany, New York, and Montreal, Québec, Canada and USA.

VERMONT AGENCY OF NATURAL RESOURCES and NEW YORK STATE DEPARTMENT OF ENVIROMENTAL CONSERVATION (1992) Vermont - New York Permit Exchange Agreement. VTANR and NYSDEC, Waterbury, Vermont and Albany, New York, USA.
VERMONT AGENCY OF NATURAL RESOURCES, NEW YORK STATE DEPARTMENT OF ENVIRONMENTAL CONSERVATION, and Québec MINISTRY OF ENVIRONMENT (1993) Lake Champlain Water Quality Agreement. VTANR, NYSDEC, and QMENV, Waterbury, Vermont, Albany, New York, and Montreal, Québec, Canada and USA.

VERMONT AGENCY OF NATURAL RESOURCES AND NEW YORK STATE DEPARTMENT OF ENVIRONMENTAL CONSERVATION (2002) Lake Champlain Phosphorus Total Maximum Daily Load (TMDL). VTANR and NYSDEC, Waterbury, Vermont and Albany, New York, USA.

VERMONT DEPARTMENT OF ENVIRONMENTAL CONSERVATION and NEW YORK STATE DEPARTMENT OF ENVIRONMENTAL CONSERVATION (1997) A Phosphorus Budget, Model, and Load Reduction Strategy for Lake Champlain. Lake Champlain Diagnostic Feasibility Study Final Report. VTDEC and NYSDEC, Waterbury, Vermont and Albany, New York, USA.

VERMONT STATE, NEW YORK STATE, and Québec PROVINCE (2003) Memorandum of Understanding on Environmental Cooperation on the Management of Lake Champlain. Vermont State, New York State, and Québec Province, Montpelier, Vermont, Albany, New York, Québec City, Québec, Canada and USA.

VERMONT STATE (2003) Clean and Clear Action Plan. Governor's Office, Montpelier, Vermont, USA.

YOUNG O (1998) North American resource regimes: institutionalized Canadian-American relations. Arizona J. Int. Comp. Law 15 289317. 